\title{
An Empirical Study on English Graded Teaching Jun GUAN
}

\author{
Wuchang Shouyi University, Wuhan, Hubei, China
}

\begin{abstract}
Keywords: English Graded Teaching; English Teaching Reform; Empirical Analysis.
\end{abstract}
\begin{abstract}
In our school, students' English foundations are in different levels. Facing this situation, if we continue to adopt the traditional teaching mode, in other words, unified class type, unified teaching schedule, the unchangeable teaching content, teaching materials and the teaching object, it will inevitably hinder the quality of English teaching. In order to improve the teaching quality, in line with the principle of education object, the English graded teaching arises at the historic moment. This study adopts the method of empirical analysis, the subjects are the total population of students from Grade 2015 and Grade 2016 in Wuchang Shouyi University (students from Grade 2015 use the traditional English teaching methods, students from Grade 2016 use the English graded teaching methods), T tests are carried out to compare the CET 4 overall score between two groups and analyze students' performance in different sections: listening, reading, writing, and integrated test. The research results show that the effect of the graded teaching is obvious with data-analysis, in which the effect of the listening part is the best. In addition, the article also analyzes the reasons of the improvement and the existing problems, which would provide reference materials for other schools avoid detours, effectively implement English teaching reform faster and achieve good effect. This essay aims to make the college English teaching achieve good effect, all teachers and students can give full play to its subjectivity.
\end{abstract}

\section{Introduction}

In recent years, how to reform college English teaching and create a new teaching ideology and how to design effective teaching mode and cultivate the wholly students linguistic comprehensive application ability have become the themes of college English teaching and exploration [1]. With enrollment expansion annually, the English proficiency of college students is also very different. Faced with the situation, many colleges and universities are taking measures to reform college English teaching mode and teaching methods.

Therefore, the best way is to provide "comprehensible input" in low anxiety situations, containing messages that students really want to hear. These methods do not force early production in the second language, but allow students to produce when they are "ready", recognizing that improvement comes from supplying communicative and comprehensible input, rather than forcing and correcting production [2].

L2 acquisition is an evolving process during which the stimulation of learning motivation is of great significance. Psychologists believe that motivation is the internal psychological tendencies or internal drives that promote the activities of the individual to achieve a certain purpose. The motivation of foreign language learners refers to the desire and/or drive of the learners to learn the language.

When it comes to English leaning, we should keep a sense of the learners as individuals. This does not only come from a humanistic concern for the welfare of the individual. It also demonstrates that learners differ in ways that need careful thought in making decisions about course content and methodology. Individual characteristics of learners may be directly or indirectly related to achievement in foreign language learning. So, we can not teach all the students by the same method. However, the identification and classification of the different individual factors have proved to be problematic. The main difficulty is that it is not possible to observe directly qualities such as aptitude, motivation, or anxiety. Aptitude, learning styles and learning strategies, the affective factors of personality and motivation are the four individual factors teachers may build awareness of. 
English graded teaching divides students from the same level into one category. A global learner is believed to prefer learning through global exposure while an analytic learner likes to analyze elements in detail. This might influence the learner's response to methods for presenting language [3]. For example, in dealing with a text, a global learner might predict and infer to get a comprehensive understanding, while an analytic learner might search for small details and try to follow accurately the precise relationships between different parts of the text. Some learners can tolerate ambiguity better than others and wait for further, disambiguating information.

Any individual may be influenced by a variety of motivations which will affect such things as anxiety, or attitude, or willingness to try new learning strategies. Learners' motivation is one of the key factors that influence the learners' achievements in their foreign language study, as the higher the motivation, the harder the study, the longer he or she will persist. English graded teaching can help to inspire students to learn English. Let us say that, given motivation, it is inevitable that a human being will learn a second language if he is exposed to the language data. Most language teachers agree that students' learning motivation is one of the most important factors influencing their success or failure in learning the language. Indeed this is a truism applicable to any other school subjects.

\section{Methodology}

\subsection{Research Questions}

Now most of the gradation teaching research articles are argumentative, this essay bases on the empirical analysis of students' test scores and uses data-analysis to demonstrated the effect of the graded teaching. The following is the questions which will be resolved in the essay.

1. Does college English graded teaching significantly improve the English of the college students?

2. Which English skill of the college students is most and least improved by means of college English graded teaching?

\subsection{Subjects}

The subjects in this study were the total population of students from Grade 2015 and Grade 2016 in Wuchang Shouyi University. They are from 8 different departments of the college, such as Computer science, Journalism, International Economy and Trade; the rates of the male student sand female students are equal, $49 \%$ and $51 \%$ respectively. Since students' enrollment into the university, two different teaching methods were adopted to Grade 2015 and Grade 2016. Students from Grade 2015 use the traditional English teaching methods, and students from Grade 2016 use the English graded teaching methods.

\subsubsection{Grade 2015: traditional teaching method}

Students from Grade 2015 use the traditional English teaching methods that is all students are divided into the all classes just by random, and received the same English teaching schedule and contents.

\subsubsection{Grade 2016: graded teaching method}

In 2016, our English department carried out the college English teaching reform for the non-English majors. According to the NMET (National Matriculation English Test) scores of the freshmen, students are divided into two levels of class, that is improved class and normal class (A class and B class for short respectively). Students of B class learn from the first volume of the new horizon college English, finish the four English semesters in normal teaching schedule, and take the national CET-4 test in the third term; students of A class learn from the second volume of the new horizon college English (volume 1 for self-study), and take the national CET-4 test in the second term. The proportion of the students in each class, textbook and teaching goals are as the follows: 
Table 1. The proportion of the students in each class, textbook and teaching goals

\begin{tabular}{l|l|l}
\hline & A level student (10-15\%) & B level student (70-80\%) \\
\hline textbook & $\begin{array}{l}\text { the new horizon college English } \\
\text { (volume 1-4) }\end{array}$ & $\begin{array}{l}\text { the new horizon college English (volume } \\
1-4)\end{array}$ \\
\hline $\begin{array}{l}\text { Teaching } \\
\text { goal }\end{array}$ & $\begin{array}{l}\text { All of the students pass the CET-4; Part } \\
\text { of them pass the CET-6 and have strong } \\
\text { capacity of listening and speaking }\end{array}$ & $\begin{array}{l}\text { Most of them pass the CET-4 and can } \\
\text { speak and listen }\end{array}$ \\
\hline
\end{tabular}

In the teaching course arrangement, for A level students, in order to ensure the quality of teaching, teachers can accelerate the teaching speed to make teaching contents to a wider and deeper; for B level students, teachers make moderate teaching schedule, organize the teaching content steadily.

To create equal opportunities for all students to compete, we make the regular adjustment for the two level classes with a term for an adjustment stage, based on the final exam score of the students of each term. This kind of system can make the students of the A level class have the crisis and "the relegation" consciousness, fully mobilize students' learning motivation, and strengthen the sense of their competition. At the same time, it can also bring stress to the teachers and urge them to spend more care on class, thus improving the overall quality of college English teaching.

Based on the random sampling method, a sample of 100 students was selected from each grade for the major analysis. The average age for the Grade 2015 sample is 21.6 years old while 20.7 years old for the Grade 2016 sample. It happened that in both grade samples, there are 55 male students and 45 female students.

Participants' NMET (National Matriculation English Test) scores provide information about their original English proficiency levels at enrollment. Table 2 describes the general statistical data about 200 samples' NMET scores distribution. A further independent sample t-test proves that there is no significant difference in statistics $(\mathrm{p}>0.05, \mathrm{t}=0.463)$ between these two groups. Because the "mean", "Std. Deviation" and "Std. Error Mean" of the two groups of the students are similar.

Table 2. NMET sample scores of Grade 2015 \& 2016

\begin{tabular}{c|c|c|c|c|c}
\hline & Grade & $\mathrm{N}$ & Mean & Std. Deviation & Std. Error Mean \\
\hline \multirow{2}{*}{ NMET } & 2015 & 100 & 95.02 & 14.315 & 1.432 \\
\cline { 2 - 6 } & 2016 & 100 & 96.53 & 14.697 & 1.470 \\
\hline
\end{tabular}

\subsection{Instruments}

The instrument analyzed in this study is the official national CET 4 test, which consisted of four sections: listening comprehension, reading comprehension, integrated test and written expression (NCETC, 2006). All the samples have taken more than once CET 4 tests after completing four-semester college English course. The data obtained in this study is subject to the latest scores provided by the students. The proportion of listening comprehension rises to $35 \%$, in which listening dialogues and listening passages are $15 \%$ and $20 \%$ respectively. Hearing conversation part includes eight short dialogues and two long conversations; listening passage parts includes compound dictation and multiple choice of understanding; hearing themes select various materials, such as dialogue, lectures, radio and television programs. The proportion of reading comprehension are adjusted for $35 \%$, in which careful reading and fast reading are $25 \%$ and $10 \%$ respectively. Besides the test of reading comprehension, the careful reading also includes the test of the vocabulary understanding in the content of the passage. Fast reading part tests various fast reading skills. The proportion of integrated test is $15 \%$, made up of two parts. The first part is cloze test or correct $(10 \%)$, the second part is short answers or translation $(5 \%)$. The proportion of the writing test is $15 \%$, genre including argumentation, exposition, practical, etc. Each part of the test pilot stage exam content and the proportion of items are shown in table 3: 
Table 3. The contents and proportion of CET-4

\begin{tabular}{|c|c|c|c|c|}
\hline $\begin{array}{l}\text { Paper } \\
\text { Constitute }\end{array}$ & \multicolumn{2}{|c|}{ The Test Content } & Test Questions & $\begin{array}{l}\text { Propo } \\
\text { rtion }\end{array}$ \\
\hline \multirow{4}{*}{$\begin{array}{l}\text { The first part: } \\
\text { listening } \\
\text { comprehension }\end{array}$} & \multirow{2}{*}{ dialogues } & Short conversations & Multiple choice & \multirow{4}{*}{$35 \%$} \\
\hline & & Long conversations & Multiple choice & \\
\hline & \multirow{2}{*}{ passages } & passages & Multiple choice & \\
\hline & & Compound dictation & Compound dictation & \\
\hline \multirow{3}{*}{$\begin{array}{l}\text { The second } \\
\text { part: reading } \\
\text { comprehension }\end{array}$} & \multirow{2}{*}{$\begin{array}{l}\text { Careful } \\
\text { reading }\end{array}$} & Reading comprehension & Multiple choice & \multirow{3}{*}{$35 \%$} \\
\hline & & Vocabulary comprehension & Blank filling & \\
\hline & \multicolumn{2}{|c|}{ Fast reading } & $\begin{array}{l}\text { Wrong judgment }+ \text { Blanks } \\
\text { filling }\end{array}$ & \\
\hline \multirow{4}{*}{$\begin{array}{l}\text { The third part: } \\
\text { integrated test }\end{array}$} & \multirow{2}{*}{\multicolumn{2}{|c|}{ Cloze test or Correct }} & Multiple choice & \multirow{4}{*}{$15 \%$} \\
\hline & & & Identify and correct the errors & \\
\hline & \multirow{2}{*}{\multicolumn{2}{|c|}{ Short answers or Translation }} & Short answers & \\
\hline & & & Translation & \\
\hline $\begin{array}{l}\text { The fourth part: } \\
\text { writing }\end{array}$ & \multicolumn{2}{|l|}{ Writing } & Passage writing & $15 \%$ \\
\hline
\end{tabular}

The data were analyzed by the Statistical Package for the Social Sciences for Windows 11.5 (SPSS Inc., 2002). Besides descriptive data, independent sample $t$ tests were used in the main analysis. The major $t$ test was carried out to compare the CET 4 overall score between two groups. Afterwards, four similar t tests were performed individually to analyze students' performance in different sections: listening, reading, writing, and integrated test. In the end, a comparative bar chart was drawn to illustrate the general score distribution of two groups.

\section{Findings}

\subsection{Results}

\subsubsection{Independent T Test Between the Overall CET 4 Scores}

The means and the standard deviations of the overall CET 4 score between two groups are summarized in Table 4. A major independent sample $t$ test is performed to examine students' test performance difference after receiving two-year different teaching methods. The result shows that there is a significant statistical difference between the overall CET-4 score of the two groups $(\mathrm{p}<0.01, \mathrm{t}=0.00)$.

Table 4. Descriptive data of the overall CET 4 score

\begin{tabular}{c|c|c|c|c|c}
\hline & Grade & $\mathrm{N}$ & Mean & Std. Deviation & $\begin{array}{c}\text { Std. Error } \\
\text { Mean }\end{array}$ \\
\hline Overall CET & 2015 & 100 & 367.67 & 48.060 & 4.806 \\
\cline { 2 - 6 } 4 score & 2016 & 100 & 423.68 & 52.019 & 5.202 \\
\hline
\end{tabular}

\subsubsection{Independent T Test Between the Individual CET 4 Scores}

In this part, four independent sample $\mathrm{t}$ tests are executed consecutively in terms of the four sections of the CET 4 test: listening, reading, writing and integrated cloze test.

Table 5 shows the descriptive data of students' performance in the listening section. The result proves that there is a significant difference in statistics between two groups' performance in the listening section $(\mathrm{p}<0.01, \mathrm{t}=0.00)$. 
Table 5. Descriptive data of the CET 4 - listening comprehension score

\begin{tabular}{c|c|c|c|c|c}
\hline & Grade & $\mathrm{N}$ & Mean & Std. Deviation & $\begin{array}{c}\text { Std. Error } \\
\text { Mean }\end{array}$ \\
\hline \multirow{2}{*}{ Listening } & 2015 & 100 & 119.11 & 25.158 & 2.516 \\
\cline { 2 - 6 } & 2016 & 100 & 140.56 & 23.487 & 2.349 \\
\hline
\end{tabular}

Table 6 exemplifies the descriptive data of students' performance in the reading comprehension section. The result proves that there is a significant statistical difference between two groups' performance in the reading section $(\mathrm{p}<0.01, \mathrm{t}=0.00)$.

Table 6. Descriptive data of the CET 4 - reading comprehension score

\begin{tabular}{c|c|c|c|c|c}
\hline & Grade & $\mathrm{N}$ & Mean & Std. Deviation & $\begin{array}{c}\text { Std. Error } \\
\text { Mean }\end{array}$ \\
\hline \multirow{2}{*}{ Reading } & 2015 & 100 & 140.92 & 28.760 & 2.876 \\
\cline { 2 - 6 } & 2016 & 100 & 157.65 & 22.829 & 2.283 \\
\hline
\end{tabular}

Table 7 illustrates the descriptive data of students' performance in the writing section. The result shows that there is a significant difference in statistics between two groups' performance in the writing section $(\mathrm{p}<0.01, \mathrm{t}=0.00)$.

Table 7. Descriptive data of the CET 4 - writing score

\begin{tabular}{c|c|c|c|c|c}
\hline & Grade & $\mathrm{N}$ & Mean & Std. Deviation & $\begin{array}{c}\text { Std. Error } \\
\text { Mean }\end{array}$ \\
\hline \multirow{2}{*}{ Writing } & 2015 & 100 & 71.52 & 11.361 & 1.136 \\
\cline { 2 - 6 } & 2016 & 100 & 80.69 & 15.419 & 1.542 \\
\hline
\end{tabular}

Table 8 gives the descriptive data of students' performance in the integrated test task. The t test result proves that there is a significant statistical difference between two groups' performance in the integrated test task $(\mathrm{p}<0.01, \mathrm{t}=0.00)$.

Table 8. Descriptive data of the CET 4 - integrated cloze test

\begin{tabular}{c|c|c|c|c|c}
\hline & Grade & $\mathrm{N}$ & Mean & Std. Deviation & $\begin{array}{c}\text { Std. Error } \\
\text { Mean }\end{array}$ \\
\hline \multirow{2}{*}{$\begin{array}{c}\text { Integrated } \\
\text { Test }\end{array}$} & 2015 & 100 & 36.12 & 10.071 & 1.007 \\
\cline { 2 - 6 } & 2016 & 100 & 44.78 & 8.974 & .897 \\
\hline
\end{tabular}

\subsection{Discussions}

In the tables, "grade" means the grades of the students; "n" means the numbers of the students, "mean" is the average scores of the students, "Std. Deviation" and "Std. Error Mean" can show the accuracy of the test.

\subsubsection{The Overall English Level is improved by Means of College English Graded Teaching}

The results indicated that there is no significant difference in students' NMET (National Matriculation English Test) scores between these two grades, in other words, their original English proficiency levels at enrollment are similar. But in table 4, the "means" (that is average score) of score in 2015 is 367.67, while the "means" of 2016 is 423.68, which shows obviously that there is a significant statistical difference between the overall CET score of the two groups, the average score of CET-4 of the students from Grade 2016 is 50 scores higher than the score of those from Grade $2015(\mathrm{p}<0.01, \mathrm{t}=0.00)$. The data of Std. Deviation and Std. Deviation shows that the collected data is effective. So we can know that by the means of English graded teaching, the whole English level of the students is obviously improved.

\subsubsection{The Most and Least Improved English Skill by Means of College English Graded Teaching}

Meanwhile, from the tables 5-8, comparing the "means" (the average score) of 2015 and 2016, 
we can find that the different English skills of students in 2016 are all improved, especially listening and reading, the average score of both are 20 score more than those in 2015 . This part can show that during the English graded teaching, listening and reading part have improved most. The integrated test has improved least, and the average score of 2016 is just 8.9 scores more than those of 2015 .

The results of the $T$ tests can directly give out the effectiveness of the English graded teaching, which can convince us to continue the English teaching reform.

\section{Summary}

In the variety of teaching reforms, graded teaching form has been presently more and more adopted. We have implemented college English graded teaching since 2008, from which we benefited a lot through a year and a half teaching experiment. The author believes that at the present time graded teaching has realistic significance when "student-centered" teaching, learner autonomy and individualized learning are focused, which is a key means to improve students' linguistic comprehensive application abilities and a trend to develop for college English teaching.

English teaching work is similar to any other work, which need love and passion especially teachers love and passion to their job. So, what kind of English teachers can really love your English teaching work? It should be those addicted in English teaching and research and diligently seeking teaching regularity. Enthusiasm, creativity and research ability continuously transfer to be the basic motive to improve the teaching quality in English teaching. In all, the research is the theory basis to inspire enthusiasm and practice creativity.

\section{Acknowledgements}

During the process of collecting data, the Wuchang Shouyi University provided a grant that enabled me to execute this project. At the same time, many colleagues gave me a lot of inspiration. I also would like to thank for the relevant organization, colleagues and researchers.

\section{References}

[1] Ministry of Education: College English Course Teaching Requirements [M]. Shanghai Foreign Language Education Press, 2015: 1-5. (In Chinese)

[2] Krashen, Stephen D. Second Language Acquisition and Second Language Learning [M]. Prentice-Hall International, 1988.

[3] Ming Yan. Graded Teaching: The New Structure of the College English Teaching Models [J]. Heilong Jiang Higher Educating Research, 2005 (2): 153-155. (In Chinese) 